\title{
Strategic management of sustainable development in the Sverdlovsk region
}

\author{
Irina Turgel ${ }^{1}$, Aleksander Pobedin ${ }^{2, *}$, and Aksanat Panzabekova ${ }^{3}$ \\ ${ }^{1}$ Ural Federal University, Mira str., 19, 620002 Yekaterinburg, Russia \\ ${ }^{2}$ Ural Institute of Management - branch of the Russian Presidential Academy of National Economy \\ and Public Administration (RANEPA), March 8 str., 66, 620144 Yekaterinburg, Russia \\ ${ }^{3}$ Institute of Economics affiliated to the Ministry of Science and Education of the Republic of \\ Kazakhstan, Kurmangazy str., 29, 050010 Almaty, Kazakhstan
}

\begin{abstract}
The implementation of the sustainable development goals requires the coordinated activities at all levels of government and administration, including the regional level. The Sverdlovsk Region, one of the leading regions of the Russian Federation, actively uses the mechanisms of the strategic management in making the socio-economic policy, however, the coordination of the traditional strategic priorities and goals of sustainable development of the UN is required. Comparison of the SDGs and strategic policy directions implemented in the Sverdlovsk region made it possible to identify three groups of SDGs: highly reflected in strategic documents, partially implemented and not yet reflected in making a regional strategy. Despite the high level of coordination of the SDGs and the strategic objectives of the region, there are the problematic areas, including the activities to combat poverty and gender policy.
\end{abstract}

\section{Introduction}

In 2015, the UN General Assembly adopted the Agenda for Sustainable Development until 2030 (hereinafter - Agenda 2030), containing 17 sustainable development goals (hereinafter - SDGs) aimed at the balanced development of the three basic components of society's development - the economy, social sphere and solving environmental problems. The SDGs continue to implement the ideas of the paradigm of a balanced and responsible global governance mechanism, which was laid back in 1987 (Report of the World Commission on Environment and Development). Currently, the paradigm of the sustainable development is designed to help countries and regions of the world successfully adapt, including to such global trends as digitalization, demographic changes and urbanization. One of the conditions for the successful implementation of the SDGs is a coordinated policy both at the international level and at the level of individual countries, as well as regions and settlements.

In this context, it seems important to coordinate the strategic goals implemented in the regions of the Russian Federation with the SDGs. The Sverdlovsk region, as one of the leading regions of Russia, has been working on strategic planning of socio-economic development over the past two decades, including integrating the sustainable development

\footnotetext{
*Corresponding author: pobedin-aa@ranepa.ru
} 
directions into the strategic documents [1]. Since 2014, since the entry into force of the provisions of the Federal Law "On Strategic Planning in the Russian Federation" [2], the strategy of socio-economic development adopted at the level of the constituent entity of the Russian Federation has become the fundamental document of the regional level, integrating the strategic priorities of the region. Therefore, it is through the regional strategies that the foundations for the implementation of the SDGs should be laid at the level of the constituent entities of the Russian Federation.

\section{Materials and Methods}

The main information background of the study is the strategic planning documents of the Sverdlovsk region, including the strategy of social and economic development, the plan for the implementation of the strategy, state programs of the Sverdlovsk region, the passports of projects implemented in the Sverdlovsk region. Access to legal information was carried out through the Consultant Plus legal reference system.

Research stages:

1. Based on the text of the strategic documents, a list of the main directions of the socioeconomic development of the region, as well as regional projects aimed at their implementation has been compiled;

2. There has been conducted a meaningful analysis of tasks and planned results for each of the strategic directions

3. Strategic directions of the Sverdlovsk region are distributed according to the UN sustainable development goals

4. The degree to which the SDGs are covered by regional-level objectives has been determined. The following conditional scale was used to grade the degree of coverage: high (a significant part of the tasks set forth in UN documents can be correlated with the objectives of the regional strategy), medium (in part, the SDG objectives correlate with the objectives of the strategy), low (the corresponding SDGs are weakly correlated with the objectives of the strategy).

A similar approach was used in the OECD Report on the implementation of the SDGs at the regional level [3].

\section{Results and Discussion}

In the Sverdlovsk region, the Strategy for the socio-economic development of the Sverdlovsk region for 2016 - 2030 (hereinafter referred to as the Strategy), adopted in 2015, is currently in force. The Strategy defines two main goals of the socio-economic policy of the region: improving the quality of life of the population, which represents the Sverdlovsk region as an attractive territory for human life and development, and increasing the competitiveness of the Sverdlovsk region in the global economy. In establishing the goals, there is direct coordination with the main directions of the sustainable development - economic development (global competitiveness), social development (quality of life) and ecological balance (a territory attractive for human life and development), although the ecological component is less pronounced, combined with a social goal. However, all three directions are designated as separate priorities of the region's socio-economic policy: accumulation and preservation of human potential; increasing the competitiveness of industrial, innovation and entrepreneurial potential; balanced development of the territory. The directions of socioeconomic policy are listed by the priorities, in each of the directions the tasks, the ongoing projects and the expected results are indicated in the form of quantitative indicators. 
In Table 1, the directions of socio-economic policy are correlated with the goals of the sustainable development within which these directions are implemented.

Table 1. Correlation of the SDGs with the directions of the Strategy of Socio-Economic

Development of the Sverdlovsk Region for 2016 - 2030

\begin{tabular}{|c|c|c|}
\hline SDG & Directions in the Strategy & Coverage \\
\hline Poverty eradication & & low \\
\hline $\begin{array}{l}\text { Ending hunger, developing } \\
\text { agriculture. }\end{array}$ & $\begin{array}{l}\text { Development of the agro-industrial complex of the Sverdlovsk } \\
\text { region }\end{array}$ & high \\
\hline Good health and wellbeing & Public health protection & high \\
\hline Quality education & Building a competitive education & high \\
\hline Gender equality & & low \\
\hline Clean water and sanitation & $\begin{array}{l}\text { Sustainable environmental development of the territory of the } \\
\text { Sverdlovsk region, Development of housing and and } \\
\text { communal services }\end{array}$ & medium \\
\hline Affordable and clean energy & $\begin{array}{l}\text { Development of housing and communal services } \\
\text { Development of territories of advanced economic growth } \\
\text { Sustainable ecological development of the territory of the } \\
\text { Sverdlovsk region }\end{array}$ & medium \\
\hline $\begin{array}{l}\text { Decent work and economic } \\
\text { growth }\end{array}$ & $\begin{array}{l}\text { Labor market development } \\
\text { Development of small and medium-sized businesses in the } \\
\text { Sverdlovsk region } \\
\text { Development of territories of advanced economic growth }\end{array}$ & high \\
\hline $\begin{array}{l}\text { Industrialization, innovation } \\
\text { and infrastructure }\end{array}$ & $\begin{array}{l}\text { Creating a comfortable environment for the life of residents of } \\
\text { the Sverdlovsk region } \\
\text { Increasing the competitiveness of the industrial complex of } \\
\text { the Sverdlovsk region } \\
\text { Development of innovative activities in the Sverdlovsk region } \\
\text { Increasing the investment attractiveness of the Sverdlovsk } \\
\text { region } \\
\text { Development of small and medium-sized businesses in the } \\
\text { Sverdlovsk region } \\
\text { Development of territories of advanced economic growth } \\
\text { Development of tourist potential } \\
\text { Development of the transport and logistics potential of the } \\
\text { Sverdlovsk region }\end{array}$ & high \\
\hline Reducing an inequality & $\begin{array}{l}\text { Development of housing and communal services } \\
\text { Creating a comfortable environment for the life of the } \\
\text { residents } \\
\text { Balanced development of municipal territories }\end{array}$ & medium \\
\hline Sustainable cities and towns & $\begin{array}{l}\text { Development of housing and communal services } \\
\text { Development of territories of advanced economic growth } \\
\text { Balanced development of municipal territories }\end{array}$ & high \\
\hline $\begin{array}{l}\text { Responsible consumption } \\
\text { and production }\end{array}$ & $\begin{array}{l}\text { Sustainable ecological development of the territory of the } \\
\text { Sverdlovsk region }\end{array}$ & medium \\
\hline $\begin{array}{l}\text { Combating the climate } \\
\text { change }\end{array}$ & & low \\
\hline $\begin{array}{l}\text { Conservation of marine } \\
\text { ecosystems }\end{array}$ & & low \\
\hline $\begin{array}{l}\text { Conservation of terrestrial } \\
\text { ecosystems }\end{array}$ & $\begin{array}{l}\text { Sustainable ecological development of the territory of the } \\
\text { Sverdlovsk region }\end{array}$ & medium \\
\hline $\begin{array}{l}\text { Peace, justice and strong } \\
\text { institutions }\end{array}$ & & low \\
\hline $\begin{array}{l}\text { Partnership for sustainable } \\
\text { development }\end{array}$ & & low \\
\hline
\end{tabular}

As can be seen from Table 1, a significant part of the priorities of the Strategy can be quite clearly correlated with the SDGs, however, the distribution of the priorities for the SDGs is uneven, there are goals - covered more fully, there are - partially implemented, and some goals are not implemented in the Strategy. Of all 17 SDGs, the ninth goal - "building resilient infrastructure, promoting inclusive and sustainable industrialization and innovation" 
- was the most in demand - eight areas of socio-economic policy implemented through ten projects are directly related to it. Economic development has always been an advantage of the region, and this is reflected in the strategic documents developed in the Sverdlovsk region; a significant part of the research is devoted to this direction $[4,5,6,7]$. Also, the coverage of goals 3 and 4 can be considered quite complete - they perfectly correlate with such strategic directions enshrined in the Strategy, such as "public health protection" and "creation of competitive education"; several regional projects are aimed at the implementation thereof. Such direction as "development of the agro-industrial complex of the Sverdlovsk region" (together with the corresponding project) is perfectly integrated into the SDG system.

The goals of "sustainable cities and settlements" correspond to the strategic priority of the Strategy - "balanced development of the territory", which includes three areas of socioeconomic policy implemented within five regional projects, including the project for the development of the Yekaterinburg agglomeration [8]. Moreover, the tasks solved within the framework of these areas may overlap in volume the corresponding tasks provided for in the 2030 Agenda, or relate to other SDGs. Particularly noteworthy is the direction of "balanced development of the territories of municipalities", affecting only the goal of urban development, but also the goal of reducing inequality [9].

For the remaining SDGs, the correlation with the directions and projects enshrined in the Strategy is not so clear. Some directions partially cover more than one SDG goal, for example, the "sustainable environmental development of the territory of the Sverdlovsk region" direction corresponds to four SDGs at once, but does not fully cover them. For example, the goal of "responsible consumption and production" implies, among other things, the solution of the problem of reducing the amount of food waste both in the sale of goods and in the process of consumption, but this task is solved both by the Clean Environment project and the state program in general; this project is a part thereof. In addition, a greater number of projects are being implemented in the region than is indicated in the strategy - this is how the regional projects "Clean Country", "Clean Air" and "Clean Water", which are not mentioned in the Strategy, have an environmental focus. Researchers note that there are problems in the region of interrelation of the scenarios for predicting the socio-economic development of the region with the expected parameters of energy consumption in the region [10], planning in the field of environmental development, in particular, regional strategic documents do not contain economic guidelines suitable for the effective development of forest farms [11].

The first, fifth, thirteenth, fourteenth, sixteenth and seventeenth SDGs were not at all reflected in the Strategy. This is partly due to the fact that some goals are either not relevant at the regional level (for example, the goal of preserving marine ecosystems does not make sense for the Sverdlovsk region, located in the continental part of the Russian Federation), or the regional administration does not have the necessary powers to implement them (for example, a significant part of the powers for the implementation of Goal 16, concerning the development of the law enforcement system, belongs to the federal level of government). However, questions remain regarding the first SDG, "poverty eradication". According to Rosstat data for 2019, the indicator of the population with incomes below the subsistence level was $8.9 \%$ for the Sverdlovsk region (i.e. the problem is quite relevant for the region, although the level of this indicator is lower than the value for the Russian Federation - 12.3). Currently, at the regional level, a program to combat poverty is being developed, which is planned to be adopted during 2020. Similarly, the Strategy did not reflect the goal of "gender equality" (this is typical for the country as a whole [12]), however, this issue is present on the agenda of some non-governmental organizations, in particular, gender policy is declared as one of their activities. The Federation of Trade Unions of the Sverdlovsk Region (FTUSR), research organizations in the region are conducting research in this area [13]. In addition, 
as noted above, certain activities related to the implementation of the SDGs can be carried out by the state, despite the absence of indications in the Strategy - for example, one of the tasks for goal 16 is the fight against corruption, this activity is carried out by the Commission on the coordination of anti-corruption work in the Sverdlovsk region, whose report for 2019 contains the results of a survey of business representatives on the change in the level of corruption. The poll showed the following results: $26.8 \%$ of the respondents believe that the level of corruption has not changed, $26.8 \%$ - decreased, $10.7 \%$ - increased, which, at least, indicates the urgency of this problem in the region, as well as in the country in the whole [14].

The Strategy states that the Government of the region annually compiles a Report on the implementation of the Action Plan for the implementation of the Strategy. As of September 2020, the latest published report was compiled based on the results of 2018 and reflects the results of the implementation of the Strategy over a three-year period [14]. According to this document, $85 \%$ of the indicators set out in the Strategy correspond to the planned values.

\section{Conclusions}

1. The analysis showed that the strategic priorities and directions of the socio-economic policy of the Sverdlovsk region are largely correlated with the priorities of the SDGs, although the structuring of goal-setting in the Strategy of the Sverdlovsk region differs significantly from that adopted in the SDGs.

2. Out of $17 \mathrm{SDGs}$, at the regional level we can speak of a high degree of coordination of regional priorities for $6 \mathrm{SDG}$, for 4 SDGs the degree of coordination is medium, 6 SDGs are weakly traced in the strategic documents of the region.

3. To the greatest extent, the content of the strategic objectives implemented in the Sverdlovsk Region coincides with SDGs 3, 4, 8, 9 and 11: "good health and well-being"; "quality education"; decent work and economic growth; "industrialization, innovation and infrastructure"; "sustainable cities and towns", which can be explained by the traditional presence of these directions in the planning and program documents of the region.

4. The SDGs that are not reflected in the Strategy of the Sverdlovsk Region can be divided into three groups: firstly, they are not relevant for the region (SDG 14), and secondly, they do not correspond in terms of the scope of powers to the subjects of competence of the regional level of government of the Russian Federation (SDGs 13, 16 and 17), thirdly, relevant for the region, but not highlighted as priorities (SDGs 1 and 5), however, in an area close to SDG 1 (poverty eradication), a regional program is currently being developed, and SDG 5 (gender equality) is partially covered by the activities of non-governmental organizations.

\section{References}

1. N. Smirnov, E. Menshikova, Transactions on Ecology and the Environment, 1 (2014)

2. E.B. Filatov, V.I. Filatov, Economic and social changes-facts trends forecast, 11 (2018)

3. A Territorial Approach to the Sustainable Development Goals: Synthesis report, OECD Urban Policy Reviews (2020)

4. I. Turgel, L. Bozhko, E. Pracheva, A. Naizabekov, Environmental and Climate Technologies, 23 (2019)

5. A.S. Gusev, Y.L. Baykin, N.V. Vashukevich, A.A. Belichev, Journal of Environmental Management and Tourism, 11 (2020)

6. M.N. Rudenko, Journal of Advanced Research in Law and Economics, 11 (2020) 
7. L.M. Averina, D.V. Sirotin, Economy of Region, 16 (2020)

8. A.A. Pobedin, Municipality: economics and management, 3 (2012)

9. I. Turgel, L. Bozhko, E. Ulyanova, A. Khabdullin, Environmental and Climate Technologies, 23 (2019)

10. V.V. Dobrodey, Economy of region, 2 (2015)

11. N. Pryadilina, D. Roy, Increasing the Use of Wood in the Global Bio Economy Proceedings of Scientific Papers, 354 (2018)

12. N.V. Chub, F.M. Cecere, Public administration issues, 1 (2020)

13. E.Kh. Tukhtarova, A.I. Kuzmin, N.P. Neklyudova, Economy of Region, 14 (2018)

14. P. Blavatskyy, Economics of transition and institutional change (2020) 